\title{
SISTEM PRIOTEKSI RADIASI : Analisis Terhadap Bidang Radiologi Rumah Sakit
}

\author{
Edi Daenuri Anwar
}

\begin{abstract}
Abstrak
Fisika kesehatan berkembang sangat pesat, hal tersebut merupakan tuntutan yang harus terpenuhi seiring dengan perkembangan kedokteran dan penyakit yang multi kompleks. Fisika menawarkan berbagai konsep untuk memudahkan, membantu dan menjawab permaslahan dalam bidang kedokteran. Jawaban tersebut adalah munculnya berbagai alat seperti CT-Scan, general x-ray, dan lain-lain. Alat- alat tersebut disebut sebagai alat-lat radiologi yang berfungsi untuk perawatan (terapi), diagnosa dan pembunuhan penyakit tanpa melakukan operasi. Tetapi disamping kemudahan-kemudahan yang diberikan ternyata alat-alat tersebut juga memberikan efek negative bagi tubuh yang terkena paparan radiasi.

General x-ray atu sering disebut sinar-x merupakan alat yang dimiliki banyak rumah sakit, kebanyakan untuk mendiagnosa suatu penyakit. Untuk meminimalisir efek negative yang ditimbulkan maka perlu adanya system proteksi yang baik, sehingga aman bagi pengguna,operator, dokter, pasien dan masyarakat pada umumnya.
\end{abstract}

Kata kunci : sinar-x, diagnosa 


\section{A. PENDAHULUAN}

Rumah sakit adalah lembaga yang penting dalam bidang kesehatan. Rumah sakit terdiri dari beberapa bagian yang menangani beberapa masalah yang berkaitan dengan penyakit dan kesehatan, misalnya untuk terapi, diagnosa, perawatan dan lain-lain. Misalnya untuk terapi, dan diagnosa rumah sakit mempunyai beberapa alat untuk melakukan fungsi tersebut. Alat-alat tersebut ada dalambagian radiologi,misalnya MRI, CT scan,general-ray dan lain-lain.

X-ray atau secara umum disebut sinar-x berguna untuk terapi dan diagnosa suatu penyakit. Penggunaan sinar-x untuk diagnosa sangat mnenguntungkan karena dapat mengetahui keadaan dalam tubuh tanpa pembedahan maupun pembelahan dari pasien. Di samping itu sianr-Xmemiliki beberapa keuntungan antara lain :

1. Mendiagnosa sesuatu dalam jangka yang relatif pendek

2. Non invasiva (tanpa pembedahan atauoperasi)

3. Mempunyai efek yang relatif kecilterhadap operator maupun pasien

4. Dapat mendiagnosa seluruh tubuh manusia

Keadaan tubuh dari pasien yang dilakukan penyinaran terhadap sinar-x dapat dilihat dari hasil citra pada film,sehingga akan memberikan informasi yang akurat mengenai keadaan tubuh yang sebenarnya.

Selain memberikan sifat yang menguntungkan ternyata sinar-x juga memberikan sifat yang merugikan yaitu sinar yang dikeluarkan dari general $x$-ray mempunyai sifat ionisasi terhadap suatu jaringan yang dilewatinya, sehingga apabila sinar- $x$ tersebut mengenai manusia secara berlebihan maka akan dapat mengakibatkan efek-efek yang merugikan. Karena itu baik operator x-ray maupun pasien harus berhati-hati terhadap sinar-x. Efek tersebut tersebut dapat diminimalisir dengan sistem proteksi radiasi yang menjamin keamanan bagi pasien,operator dan masyarkat umum. 


\section{B. DEFINISI RADIASI DAN PENGGOLONGANNYA}

Definisi radiasi menurut Muhlis (2000:28) adalah pancaran. Misalnya matahari dikatakan sebagai sumber radiasi karena dapat memancarkan radiasi dalam bentuk cahaya. Radiasi dibagi dua yaitu radiasi pengion dan radiasi bukan pengion. Sedangkan radiasi pengion terbagi menjadi dua yaitu radiasi elektromagnetik dan radiasi partikel.

\section{Radiasi elektromagnetik}

Hipotesis mengenai radiasi elektromagnetik dikemukakan oleh fisikawan inggris James Clark pada tahun 1984 : perubahan medan magnet dapat menimbulkan medan listrik, sebaliknya dapat pula perubahan medan listrik dapat pula menimbulkan medan magnet " (Muhlis,2000;30) Setelah meninggal dunia, hipotesis tentang adanya radiasi elektromagnetik dibuktikan oleh Heinrich Rudolf Hertz. Hasil percobaan membuktikan bahwa radiasi elektromagnetik merambat dengan kecepatan sama dengan kecepatan cahaya serta memeiliki sifat-sifat yang sama dengan cahaya, seperti yang diramalkan oleh Maxwell sebelumnya. Akhirnya dari beberapa percobaan membuktikan bahwa radiasi elektromagnetik ini merupakan penjalaran atau perambatan medan listrik dan medan magnet yang saling tegak lurus. Dari pengelompokan dan klasifikasi gelombang elektromagnetik maka dapat di simpulkan bahwa sinar-x termasuk dalam kategori gelombang elektromagnetik.

\section{Energi radisi elektromagnetik pada sinar $-x$}

Radiasi elektromagnetik memiliki energi yang rumusnya sesuai dengan ketetapan Planck yaitu $E=h v$. Dan dalam satuan internasional satuan dari energi adalah joule, karena untuk energi radiasi elektromagnetik energinya kecil sehingga menggunakan satuan elektronvolt. Sinar-x pertama kali ditemukan oleh fisikawan berkebangsaan jerman Wilhelm C.Rontgen pada tanggal 8 november 1985. Pada saat Rontgen menyalakan sumber listrik tabung untuk penelitian katoda, beliau mendapatkan sejenis cahaya berpendar pada layar yang terbuat dari barium, 
platina cyanida yang kebetulan berada didekatnya. Jika sumber listrik dipadamkan sinarpun menghilang, ternyata sinar tersebut muncul dari sinar katoda. Karena sebelumnya belum pernah dikenal sehingga disebut sinar-x.

Sifat-sifat sinar-x telah terungkap pada percobaan rontgen yaitu sinar- $x$ dapat memendarkan berbagai jenis bahan kimia dan juga dapat menembus materi yang tidak dapat ditembus oleh sinar yang lain.

Sifat-sifat sinar-x antara lain:

- Sinar-x dapat menembus hampir semua materi atau bahan

- Penyerapan (absorption), sinar-x diserap oleh bahan atau zat sesuai dengan berat atom atau kepadatan bahan.

- Efek fotografik, sinar-x dapat menghitamkan emulsi film (emulsi perak bromida) setelah diproses secara kimiawi

- Ber pendar, Sinar-x dapat menyebabkan bahanbahan tertentu seperti kalsium tungestan atau seng sulfide berpendar

- Ionisasi,Sinar-x dapat mengionisasi bahan atua suatu zat sehingga berubah strukturnya

- Sinar-x tidak berpengaruh oleh medan listrik maupun medan listrik maupun medan magnet

- Pertebaran (scattering), Apabila sinar -x melalui suatu bahan maka berkas tersebut akan bertebaran ke segala arah yang akan menimbulkan radiasi sekunder pada bahan-bahan yang dilaluinya

- Merupakan gelombang elektromagnetik 


\section{Proses untuk menghasilkan Sinar-x}

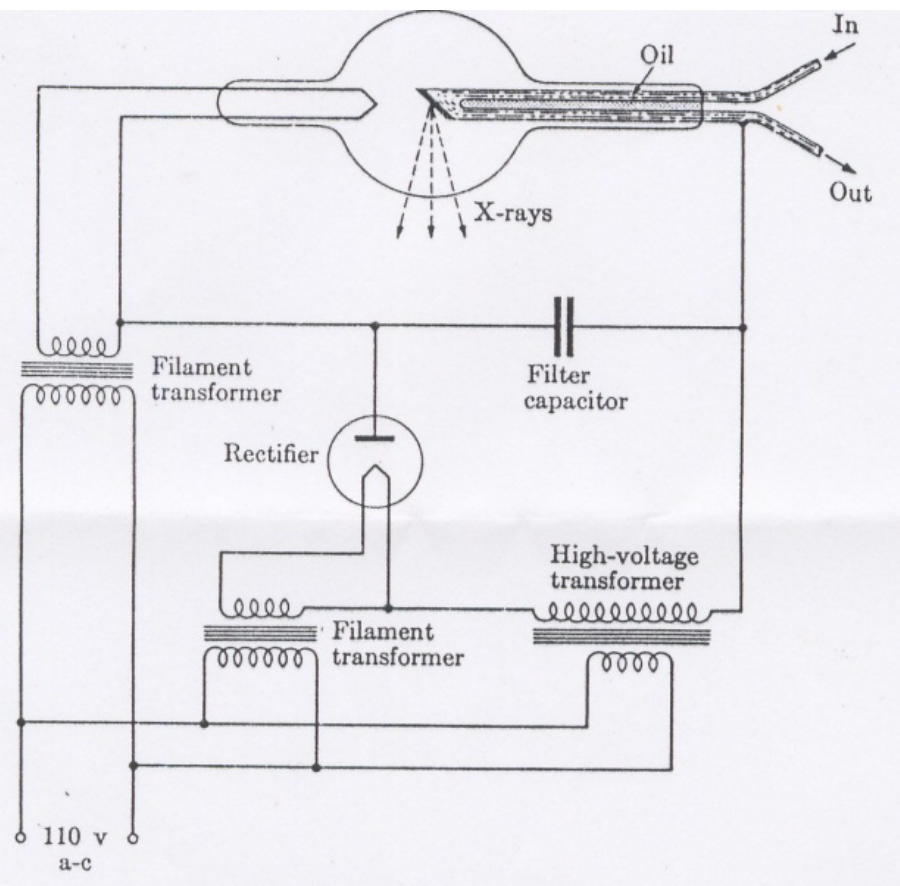

Gambar 1. Pesawat sinar-x (General $x$-ray)

Secara umum cara terbentuknya sinar-x terbagi menjadi dua yaitu sinar-x karakteristik dan sinar-x bremstrahlung. Mengenai sinar- $x$ karakteristik adalah apabila ada elektron yang menumbuk suatu atom, apabila elektron tersebut mengenai elektron pada kulit yang paling rendah tingkat energinya, sehingga elektron tersebut akan terpental dan kekosongan tersebut akan diisi oleh elektron yang berada diatasnya dan pada perpindahan tersebut elektron harus mengeluarkan energy dalam bentuk foton yang disebut dengan sinar-x karakteristik.

Pada prakteknya sinar-x dapat dihasilkan denganjalan menembaki logam target dengan elektron cepat dalam suatu tabung vakum sinar katoda, elektron sebagai proyektil yang dihasilkan dari pemanasan filamen yang berfunsi sebagai katoda. Elektron dalam filamen dipercepat gerakannnya menggunakan tegangan listrik berorde $10^{10}$ volt. Elektron yang bergerak sangat cepat itu 
akhirnya ditumbukkan ke target logam bernomor tinggi atau suhu lelehnya tinggi. Ketika elektron berenergi tinggi menabrak target logam maka sinar-x akan terpancar dari permukaan logam tersebut. Sinar-x yang melalui proses ini disebut sinar$\mathrm{x}$ bremstrahlung (pengereman). Sinar-x yang terbentuk melalui proses ini disebut mempunyai energi maksimal sama dengan energi kinetik elektron pada saat terjadinya perlambatan. Dari proses tersebut energi kinetik elektron sebagian besar diubah menjadi panas (99\%) dan 1\% menjadi energi kinetik.

Agar suatu tabung pesawat sinar-x dapat melakukan proses diatas maka harus mempunyai beberapa persyaratan antara lain :

- Sumber elektron, bahan sumber elektron adalah kawat pijar atau filamen pada katoda didalam tabung pesawat sinar-x (rontgen). Pemanasan filamen dilakukan dengan suatu transformator khusus

- Gaya yang mempercepat gerakan elektron

- Lintasan elektron yang bebas dalam ruang hampa udara

- Alat pemusat berkas elektron (Focusing Cup), alat ini yang menyebabkan sinar-x yang dikeluarkan oleh General x-ray tidak berpencar tetapi terarah ke bidang focus (focal spot)

- Penghenti gerakan elekron

Secara teknis syarat-syarat tersebut diatas terpenuhi oleh pesawat rontgen yang terdiri dari :

- Tabung gelas silindrik hampa udara

- Anoda dengan filamen yang terdiri dari kawat tung sen (mempunyai titik lebur tinggi)

- Anoda terdapat bidang focus (focal spot) yang merupakan sasaran target yang akan ditembakkan oleh elektron-elektron.

Percepatan gerakan elektron diperoleh oleh generator tegangan tinggi (transformator), pada suatu tabung sinar-x dengan lingkaran transformatornya terdapat bagian-bagian sebagai berikut : tabung silindrik hampa udara, filamen transformator, 
target (sasaran ), pelindung timah $(\mathrm{Pb})$, jendela, radiator pendingin, auto transformator dan pengukur milliamper.

Dalam tabung sinar-x terdapat katoda dan anoda, bila antara katoda dan anoda diset dengan energi tinggi maka katoda akan melepaskan elektron-elektron dengan cara emisi termionik dan bergerak dengan energi kinetik yang sangat besar menuju anoda sehingga anoda kan melepaskan energi dalam bentuk sinar-x. Secara terperinci urutan terjadinya sinar-x sebagai berikut :

1. Katoda (filamen dipanaskan lebih dari $2000^{\circ} \mathrm{C}$ sampai menyala) dengan mengalirkan listrik yang berasal dari transformator $(\mathrm{G})$

2. Karena panas, elektron-elektron dari katoda lepas

3. Sewaktu dihubungkan denga transformator tegangan tinggi, elektron akan dipercepat gerakannnya menuju anoda dan dipusatkan ke alat pemusat ( focusing cup)

4. Filamen dibuat relatif negatif terhadap sasaran

5. Awan-awn elektron mendadak dihentikan pada sasaran sehingga terbentuk panas $99 \%$ dan terbentuk sinar-x sebesar $1 \%$

6. Perisai ( timah yang berada dalam tabung mencegah keluarnya sinar-x dari tabung, sehingga sinar-x yang keluar hanya melalui jendela)

\section{Spektrum Energi sinar-x}

Dalam sinar- $x$, biasanya energi elektron yang dipercepat dengan beda potensial $v$ dirumuskan sebagai:

$$
\begin{aligned}
& E=v \cdot e \\
& E=\text { energy elektron }(e V) \\
& \mathrm{u}=\text { beda potensial } \\
& \mathrm{e}=\text { muatan elementer elektron }\left(1.6 \times 10^{-19} \mathrm{C}\right)
\end{aligned}
$$


Dengan konversi rumus $E=h . c / \lambda$ sehingga didapatkan

$$
\frac{h . c}{\lambda_{\min }}=v \cdot e
$$

Dengan $\mathrm{c}=3.10^{\mathrm{s}} \mathrm{m} / \mathrm{s}$

$$
\begin{aligned}
& \mathrm{H}=6.63 \times 10^{-34} \mathrm{JS} \\
& \mathrm{E}=1.6 \times 10^{-19} \mathrm{C}
\end{aligned}
$$

$$
\begin{gathered}
\lambda_{\text {min }}=\frac{h \cdot c}{v \cdot e} \\
\lambda_{\text {min }}=\frac{6,63 \cdot 10^{-34} \cdot 3 \cdot 10^{8}}{v \cdot 1 \cdot 6 \times 10^{-19}} \\
\lambda_{\text {min }}=\frac{12 \cdot 4 \times 10^{-7}}{v} \mathrm{~m}
\end{gathered}
$$

Dari rumus diatas dapat diketahui panjang gelombang minimal yang dihasilkan dari sinar-x.

\section{INTERAKSI SINAR-X DENGAN SEL DAN EFEKNYA}

Interaksi sinar- $x$ dengan sel biologi memiliki efek langsung dan tidak langsung. Efek langsung adalah efek yang timbul akibat terionisasi atau tereksitasinya bagian sel yang terkena paparan radiasi secara langsung, sedangkan efek tidak langsung adalah efek yang timbul akibat interaksi bahan-bahan yang dihasikan olah efek langsung dengan komponen penyusun sel. Karena sel tersusun oleh karbohidrat, lemak, protein dan sekitar 70\% sel tersusun air, amaka Interaksi radiasi dengan komponen utama penyusunan ini menyebabkan terbentuknya bahan-bahan kimia dari sel. Proses perusakan sel terjadi dengan beberapa tahap : 
A. Tahap fisis

Tahap ini merupakan tahap awal, yaitu pada saat $\mathrm{H}_{2} \mathrm{O}$ terkena radiasi, proses ini terjadi sekitar $10^{-16}$ detik dan terjadi ionisasi

$\mathrm{H}_{2} \mathrm{O} \quad \longrightarrow \quad \mathrm{H}_{2} \mathrm{O}+\mathrm{e}^{-}$

B. Tahap kimia fisik

Tahap ini berlangsung 10 detik, pada tahap ini ion-ion hasil tahap pertama terdisosiasi atau berinteraksi dengan molekul air yang lain sehingga menghasilkan produk baru.

Ion posistif terdisosiasi

$\mathrm{H}_{2} \mathrm{O} \quad \longrightarrow \mathrm{H}^{+}+\mathrm{OH}^{-}$

Ion negatif berinterkasi dengan air

$\mathrm{H}_{2} \mathrm{O}+\mathrm{e}^{-} \quad \longrightarrow \quad \mathrm{H}_{2} \mathrm{O}^{-}$

Kemudian terdisosiasi

$$
\mathrm{H}_{2} \mathrm{O}^{-} \longrightarrow \mathrm{H}^{0}+\mathrm{OH}^{\circ}
$$

Hasil reaksi diatas adalah $\mathrm{H}^{+}, \mathrm{OH}^{-}, \mathrm{H}^{\circ}$ dan $\mathrm{OH}^{\circ}$. ion-ion $\mathrm{H}^{+}$ dan $\mathrm{OH}^{-}$banyak terdapat dalam air,tidak ikut bagian pada tahap selanjutnya. Dua hasil lain yaitu $\mathrm{H}^{\circ}$ dan $\mathrm{OH}^{\circ}$ disebut radikal bebas mempunyai elektron tiap pasang dan secara kimia sangat reaktif. Hasil lain yang sangat menimbulkan kerusakan yaitu terjadinya hydrogen peroksida $\mathrm{H}_{2} \mathrm{O}_{2}$ yang merupakan oksidator kuat

$$
\mathrm{OH}^{\circ}+\mathrm{OH}^{\circ} \longrightarrow \mathrm{H}_{2} \mathrm{O}_{2}
$$

C. Tahap kimia

Tahap ini berlangsung beberapa detik, pada tahap ini hasil reaksi yaitu: $\mathrm{OH}^{\circ}$ dan $\mathrm{H}^{\circ}$ dan $\mathrm{H}_{2} \mathrm{O}_{2}$ berinteraksi dengan molekul- 
molekul organik dari sel yang mungkin saja merupakan bagian yang cukup penting bagi sel untuk manjalankan fungsinya, contoh radikal bebas dan oksidator kuat dapat mempengaruhi molekul-molekul kompleks pembentuk kromosom, sehingga bergabung dengan molekul-molekul tersebut atau dapat menyebabkan rantai molekul yang panjang terputus.

D. Tahap biologis

Tahap ini berlangsung dalam waktu sangat bervariasi dari sekitar 10 menit sampai puluhan tahun bergantung efek yang terjadi akibat dari interaksi - interaksi tahap sebelumnya dapat mempengaruhi sel secara individual dalam berbagai segi. Antara lain dapat menyebabkan :

- Kematian sel

- Terhambat dan tercegahnya pembelahan sel

- Perubahan terhadap sel yang terbawa oleh sel anak

Sedangkan efek-efek radiasi berdasarkan jenis dosisnya yaitu :

1. Penyinaran dalam waktu singkat ( akut) yang umumnya terjadi secara kebetulan (kecelakaan). Penyinaran akut yang melibatkan penyinaran dengan dosis tinggi dapat menimbulkan efek biologi seketika, yaitu efek yang kemunculannnya kurang dari satu tahun sejak terjadinya penyinaran. Tetapi penyinaran akut dapat menimbulkan efek biologis tertunda apabila dosis radiasinya rendah.

2. Penyianaran oleh dosis radiasi rendah namun berlangsung terus -menerus (kronis). Penyinaran jenis ini biasanya tidak segera menampakkan efeknya, sehingga efek yang ditimbulkan disebut efek tertunda. Efek ini dapat muncul setelah beberapa tahun bahkan puluhan tahun sejak terjadinya penyinaran.

Penyinaran radisi berlebihan yang bersifat akut terhadap seluruh tubuh akan mempengaruhi semua organ dan sistemsitem yang terdapat dalam tubuh. Namun karena tidak semua

Jurnal PHENOMENON, Volume 1 Nomor 1, Juli 2011 
organ atau sistem memiliki kepekaan yang sama terhadap radiasi maka pola-pola respon atau sindrom penyakit pada orang yang mengalami penyinaran yang berlebihan tergantung pada banyaknya dosis. Untuk menyederhanakan klasifikasi maka sindrom radiasi akut dapat muncul dengan sindrom gastroinlestinal ( yang berhubungan dengan lambung dan usus) dan sindrom sistem syaraf pusat. Selain itu ada beberapa efek yang lazim bagi sindrom radiasi akut yaitu : mual dan ingin muntah, tidak enak badan dan lesu, naiknya suhu dan adanya perubahan-perubahan darah

Sedangkan waktu timbulnya efek tersebut berdasarkan cepat lambatnya penampakan suatu efek biologis terdapat pembagian sebagai berikut :

1. Efek segera adalah efek yang pemunculannya terjadi kuarang dari satu tahun

2. Efek tertunda adalah efek yang munculnya agak lambat,lebih dari satu tahun sejak terjadinya penyinaran. Efek ini dapat disebabkan oleh penyinaran akut maupun penyinaran kronis.Berbeda dengan efek segera yanghanya diderita oleh seseorang yang dikenai penyinaran, efek tertunda dapat juga diberikan oleh turunan dari orang yang menerima penyinaran, tetapi tidak setiap orang yang menerima penyinaran kronis akan memiliki efek tertunda. Karena efek tertunda berbeda-beda sesuai dengan efek radiasi pengion, maka efek dari radiasi pengion dibagi ke dalam tiga jenis :

- Efek somatik adalah efek yang secara pasti dapat terjadi pada seseorang yang menerima penyinaran dan pasti bahwa penyebabnya adalah radiasi yang diberikan pada orang tersebut.jelas bahwa efek ini termasuk ke dalam efek segera. Efek ini timbul dengan masa tenggang yang bergantung pada dosis yang diberikan pada seseorang dan juga bergantung pada karakter biologi dari gejala yang muncul. Misalnya eritema kulit, akan muncul kira-kira jangka waktu tiga minggu setelah diberikan penyinaran dengan dosis beberapa ratus rad.Tetapi gejala yang serupa akanmuncul hanya dalam beberapa hari 
setelah penyinaran jika dosis yang diberikan lebiih dari 1000 rad.

- Efek somatik-stokastik adalah efek yang dialami sel-sel somatic pada orang yang menerima penyinaran, tetapi secara statistik beberapa efek tertunda tidak dapat dipastikan akan diderita oleh orang yang menerinma penyinaran, karena itu efek ini disebut efek somatic-stokastik. Misalnya tingginya kejadian leukimia dikalangan ahli radiologi secara statistik tidak dapat diduga secara pasti karena para ahli tersebut selalu mendapat medan radiasi. Hal ini berarti bahwa tidak semua ahli radiologi akan mengalami efek somatik (segera maupun tertunda), tetapi dapat diduga bahwa jumlah penderita leukemia yang kemungkinan dialami apara ahli radiologi akan lebih banyak jika dibandingkan dengan masyarakat yang tidak menerima radiasi penyinaran.

- Efek genetik adalah efek stokastik yang disebabkan oleh rusaknya sel genetik, oleh karena itu tidak diderita oleh yang menerima penyinaran, tetapi kemungkinan terjadi pada keturunan seseorang yang menerima penyinaran. Efek genetik ini terdistribusi pada anggota suatu kelompok secara acak dan konsekuensi kliniknya merupakan konsekuensi tertunda.

\section{SISTEM PROTEKSI RADIASI}

Karena adanya efek-efek yang sangat membahayakan bagi manusia yang terkena paparan radiasi maka untuk mengeliminir efek yang diakibatkan maka perlunya system proteksi radiasi. Untuk menentukan system proteksi, pengawasan dan standar protesi radiasi maka terdapat lembaga/badan-badan yang menetukan standar proteksi radiasi yaitu :

1. Komisi Internasional proteksi radiasi

Komisi internasional proteksi radiasi, international Commision on radiological protection (ICRP) adalah badan yang mempunyai tugas untuk menciptakan pedoman dalam hal keselamatan radiasi,membahas prinsip-prinsip dasar proteksi radiasi dan ke-

Jurnal PHENOMENON, Volume 1 Nomor 1, Juli 2011 
pada berbagai komite proteksi nasional memberikan tanggung jawab untuk memperkenalkan aturan-aturan teknis.

2. Perwakilan tenaga atom internasional

3. Komisi satuan dan pengukuran radiologi internasional

4. Dewan proteksi radiasi

5. BATAN ( badan tenaga Nuklir)

Badan inilah yang mengawasi sistem proteksi dalam bidang radiologi secara nasional.

Sistem pembatasan dosis yang dianjurkan oleh ICRP mengenai dosis radiasi, di dasarkan pada tiga prinsip yaitu :

1. Tidak ada praktek yang boleh digunakan kecuali jika prakteknya menghasilkan keuntungan positif netto

2. Semua penyinaran harus dijaga dengan dosis serendah mungkin yang dapat dicapai, faktor-faktor social ekonomi social harus dipertimbangkan

3. Dosis yang setara dengan individual harus tidak melebihi batas-batas yang direkomendasikan oleh komisi.

Selain proteksi radiasi yang telah diterapkan maka pada waktu paparan radiasi ke pasien juga perlu adanya proteksi radiasi dengan cara : eksternal adalah radisi yang dihasilkan alat-alat yang dirancang untuk menghasilkan radiasi : meminimalkan waktu penyinaran, memaksimalkan jarak dari sumber radiasi serta melindungi sumber radiasi suapaya sumber radisi hanya terpusat pada obyek.

Untuk mengukur besarnya radiasi- radiasi ionisasi yang bersifat biologis, perlu alat-alat pendeteksi radiasi. Alat - alat tersebut terbagi dua yaitu instrumen penghitung partikel dan pengukur dosis. Instrumen penghitung partikel yaitu penghitung partikel berisi gas, penghitung bilik ionisasi, penghitung proporsional, penghitung Geiger, penghitung skintilasi, spektroskopi nuklir dan detektor semikonduktor.

Sedangkan Instrumen pengukur dosis terdiri dari dosimeter saku, jenis dosimeter ini secarameluas digunakan untuk pemantauan personel (personal monitory), lencana film (film badge), dosimeter termoluminesens dan bilik arus ion

Dalam penelitian ini penulis bermaksud untuk mengetahui 
radiasi yang terima pasien dan sistem proteksi radiasi dengan menggunakan alat Geiger Muller atau disebut penghitung Geiger. Dalam halini penulis mengambil Badan Rumah Sakit Daerah (BRSD) RAA SOEWONDO sebagian kajian dalam sisntem proteksi radiasi.

Hasil ekspose di dalam ruangan (ruang radiologi)

Tabel 1. Hasil ekspose di dalam ruangan (ruang radiologi)

\begin{tabular}{|c|c|c|c|c|c|c|}
\hline No & $\begin{array}{c}\text { Jarak pa- } \\
\text { paran (m) }\end{array}$ & $\mathrm{mA}$ & $\mathrm{kV}$ & $\mathrm{t}(\mathrm{s})$ & $\begin{array}{c}\text { Paparan } \\
\text { (Count/ } \\
\text { detik) }\end{array}$ & $\begin{array}{c}\text { Paparan rata- } \\
\text { rata (Count/ } \\
\text { detik) }\end{array}$ \\
\hline 1 & 1 & 150 & 70 & 0,3 & 1465 & 1390 \\
\hline & & & & & 1315 & \\
\hline 2 & 2 & 150 & 70 & 0,3 & 563 & 553 \\
\hline & & & & & 543 & \\
\hline 3 & 3 & 150 & 70 & 0,3 & 441 & 425,5 \\
\hline & & & & & 410 & \\
\hline 4 & 4 & 150 & 70 & 0,3 & 364 & 344 \\
\hline & & & & & 324 & \\
\hline
\end{tabular}

Dari Tabel 1 dapat diketahuai bahwa walaupun jauh dari pesawat sinar-x seseorang akan tetap mendapatkan paparan radiasi. Berkurangnya radiasi yang dipancarkan oleh pesawat sinar-x (general $x$-ray) adalah sesuai dengan konsep atenuasi. Atenuasi adalah berkurangnya jumlah/intensitas sinar-x yang melalui bahan atau materi dengan cara penyerapan atau pembelokan sinar- $x$

$\mathbf{N}=\mathbf{N}_{\mathbf{o}} \cdot \mathbf{e}^{-\mu x}$

$\mathrm{N}_{\mathrm{o}}$ =jumlah foton sumber

$\mathrm{N}=$ jumlah foton yang melewati materi

$\mu=$ koefisien atenuasi

$\mathrm{X}=$ ketebalan materi penyerap 


\section{Data Ekspose di Luar Ruangan}

Data ekspose diluar ruangan hanya untuk menguji apakah diluar ruangan ketika diadakan paparan pada pasien masih ada radiasi pengion atau sudah aman dari radiasi.

Tabel 2. Hasil ekspose diluar ruangan

\begin{tabular}{|c|l|c|c|}
\hline No & Penghalang & Tebal timah $(\mathrm{d})$ & Paparan (count/time) \\
\hline 1 & Dinding ruangan & $2 \mathrm{~mm}$ & 0 \\
\hline 2 & Kaca operator & - & 0 \\
\hline 3 & Pintu ruangan & $2 \mathrm{~mm}$ & 0 \\
\hline
\end{tabular}

Dengan alat Geiger muller menunjukkan 0 ketika diluar ruang radiologi baik di bagian operator yangdihalangi kaca, balik pintu, dan dinding ruangan. Ini menunjukkan bahwa konstruksi ruangan tersebut telah aman baik bagi operator maupun maupun bagi masyarakat umum. Hal ini menunjukkan bahwa BRSD RAA Soewondo telah menerapkan system proteksi radiasi dengan baik.

Keamanan ruang radiologi tersebut karena dalam konstruksi bangunan ruang radiologi ditambahkan dengan $\mathrm{Pb}$ setebal $2 \mathrm{~mm}$. Pb atau timbal adalah logam yang dapat menyerap paparan radiasi sehingga ketika ada radiasi yang diakibatkan adanya sinar hambur maupun sinar utama maka semuanya paparan radiasi akan semuanya diserap oleh $\mathrm{Pb}$, demikian juga pintu maupun kaca operator yang dilapisi dengan $\mathrm{Pb}$. Karena telah aman maka dapat disimpulkan bahwa bagian radiologi khususnya general $x$-ray telah sesuai dengan standar sistem proteksi radiasi.

\section{E. KESIMPULAN}

Sistem proteksi radiasi adalah merupakan hal yang sangat penting dalam bidang radiologi. Kesalahan dalam penerapan system proteksi akan berakibat fatal bagi pasien, operator dan masyarakat secara umum. Paparan radiasi terhadap suatu objek harus dilakuakn setepat mungkin yang meliputi pemilihan arus 
$(\mathrm{mA})$, beda potensial $(\mathrm{kV})$ dan waktu (s) yang cocok sehingga menghasilkan gambar film yang baik tanpa merugikan pasien.

Timbal merupakan bahan penyerap radiasi sinar-x yang sangat baik, sehingga dalam pembuatan ruang radiologi perlu memperhatikan sistem proteksi radiologi. Ketebalan timbal yang digunakan sebagai proteksi radiasi arus disesuaikan dengan general x-ray yang di gunakan. Semakin besar energi yang dipancarkan maka semakin tebal pula timbal yang digunakan sebagai penyerapan. Dalam ruang radiologi BRSD RAA Soewondo dengan ketebalan timbal $2 \mathrm{~mm}$ sudah baik sebagai proteksi radiasi untuk general $\mathrm{x}$-ray yang memiliki beda potensial maksimal $150 \mathrm{kV}$. 


\section{DAFTAR PUSTAKA}

Akhadi, Mukhlis, 1997, Pengantar Teknologi Nuklir, Jakarta, Rineka Cipta

Akhadi, Mukhlis, 2000, Dasar-dasar Proteksi Radiasi, Jakarta, Rineka Cipta

Cember, Herman, 1983, Pengantar Fisika kesehatan, Semarang, IKIP Semarang Press

Richards, James, 1962, Modern University Physics, London, Addison Wesley Publishing Company

Simon, M.D, 1981, Diagnostic Rontgen, Jakarta, Erlangga

Wiryosimin, S, 1995, Mengenal Asas Proteksi Radiasi, Bandung,ITB

W, Ford,Kenneth, 1983, Basic Physics, London, A Division of Ginn and Company 